\title{
Effect of Organic Manures on Quality and Shelf Life of Beet Root Cv. Crimson Globe
}

\author{
Chitti Jagadeesh", M. Madhavi, V.V. Padmaja and M. Siva Prasad \\ Department of Vegetable Science, College of Horticulture, Dr.Y.S.R. Horticultural University, \\ Mojerla, Mahabubnagar, India \\ *Corresponding author
}

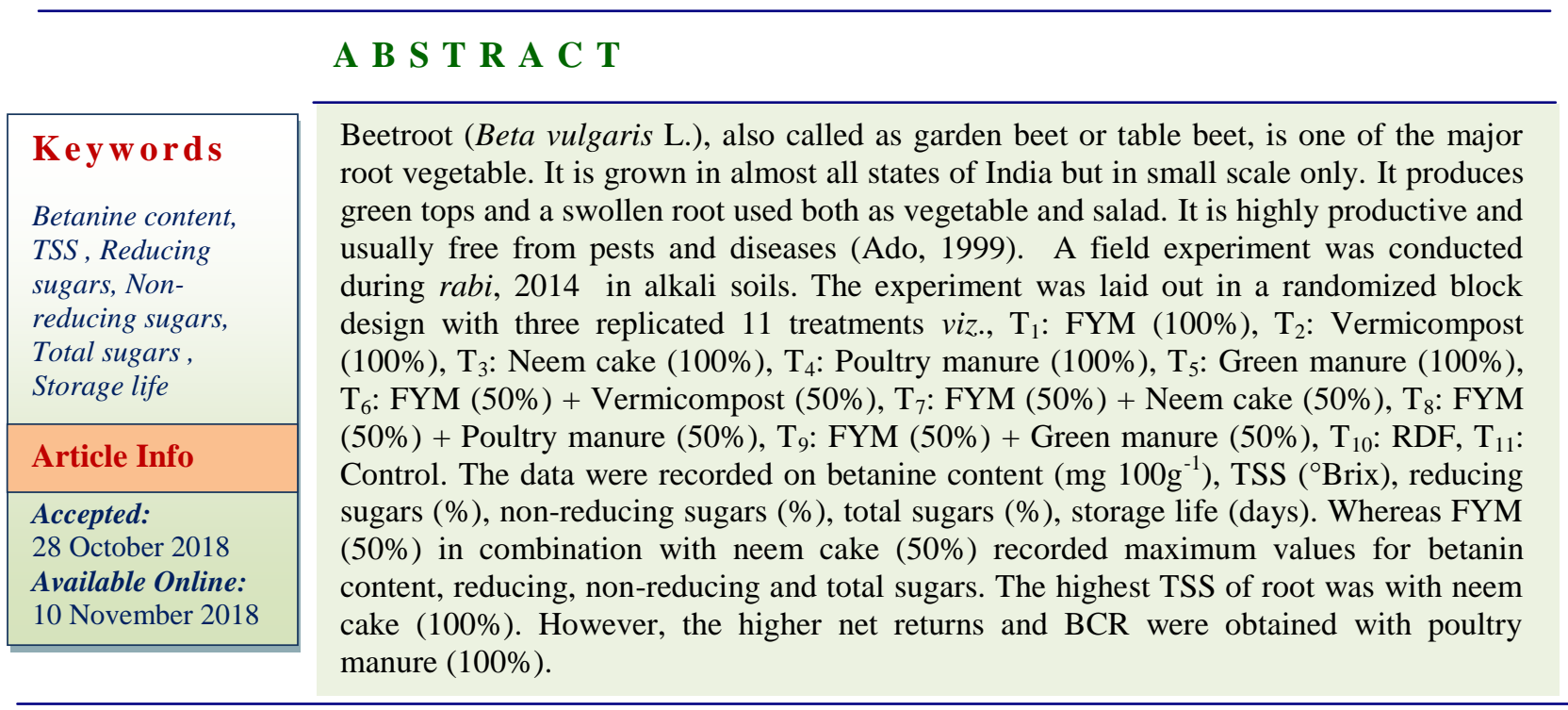

\section{Introduction}

Beetroot (Beta vulgaris L.), also called as garden beet or table beet, is one of the major root vegetable belongs to the family Chenopodiaceae along with spinach, palak, swiss chard, parsley, celery and it has chromosome number of $2 n=18$. Beet originated in Western Europe and North Africa where they were grown to feed both humans and livestock. This crop is a biennial grown as a cool season annual. It is grown in northern and southern parts of India. It is grown in almost all states of India but in small scale only. It produces green tops and a swollen root used both as vegetable and salad. It is highly productive and usually free from pests and diseases (Ado, 1999). It is a rich source of protein, carbohydrate, calcium, phosphorous and vitamin $\mathrm{C}$, hence it is an ideal vegetable for health conscious people (Deuter and Grundy, 2004). Red color of roots is due to presence of betanine pigment.

Beet root helps to reduce blood pressure, prevents plaque formation and reduces bad 
cholesterol, keeps diabetes under check, treats anaemia, helps to relieve fatigue, improves sexual health and stamina, protects from cancer, etc. Among the many constraints to increase productivity in beet root, inorganic nutrition is the main limiting factor especially in alkaline soils. The continuous use of inorganic fertilizers is adversely affecting the sustainability of production besides causing environmental pollution. In view of increased awareness about organic manuring, increased availability of organic inputs and sustainability in the farm, investigation on these aspects have thus become imperative to study and assess their effect on quality and shelf-life of beet root. Hence, this investigation is planned to identify effect of organic manures on quality and shelf life of beet root grown in alkali soils.

\section{Materials and Methods}

A field experiment was conducted during rabi, 2014 in alkali soils, at college farm, College of Horticulture, Dr. Y.S.R. Horticultural University, Mojerla, Mahabubnagar(Dt). The experiment was laid out in a randomized block design with three replicated 11 treatments viz., $\mathrm{T}_{1}$ : FYM (100\%), $\mathrm{T}_{2}$ : Vermicompost (100\%), $\mathrm{T}_{3}$ : Neem cake $(100 \%), \mathrm{T}_{4}$ : Poultry manure (100\%), $\mathrm{T}_{5}$ : Green manure (100\%), $\mathrm{T}_{6}$ : FYM $(50 \%)+$ Vermicompost $(50 \%), \mathrm{T}_{7}:$ FYM $(50 \%)+$ Neem cake $(50 \%)$, T$_{8}:$ FYM $(50 \%)+$ Poultry manure $(50 \%), \mathrm{T}_{9}$ : FYM $(50 \%)+$ Green manure (50\%), $\mathrm{T}_{10}$ : RDF, $\mathrm{T}_{11}$ : Control. The data were recorded on betanine content (mg $100 \mathrm{~g}^{-1}$ ), TSS $\left({ }^{\circ} \mathrm{Brix}\right)$, reducing sugars $(\%)$, non-reducing sugars (\%), total sugars $(\%)$, storage life (days).

\section{Root quality parameters}

\section{Total soluble solids and reducing sugars}

The total soluble solids of all the roots of five randomly selected plants from each plot was measured with the help of a hand refractometer $\left(0-28^{0} \mathrm{~B}\right)$ and the average is expressed in ${ }^{0}$ Brix. Reducing sugars were determined by the method of Lane and Eyon (AOAC, 1965). Ten grams of beetroot cube was taken, ground well and transferred to 250 $\mathrm{ml}$ volumetric flask and $2 \mathrm{ml}$ of lead acetate solution $(45 \%)$ was added to the flask to precipitate colloidal matter and kept for 24 hrs. Two ml potassium oxalate $(22 \%)$ was added to this solution to precipitate the lead acetate and the volume was made up to $250 \mathrm{ml}$ using distilled water. The contents were then filtered through Whatman No.1 filter paper after testing a little of filtrate for absence of lead by adding a drop of potassium oxalate. Reducing sugars in the filtrate were estimated by titrating against $10 \mathrm{ml}$ of standard Fehling's solution mixture of A and B (1:1) using methylene blue as an indicator till the end point was indicated by the formation of brick red precipitate.

The titration was carried out by keeping the Fehling's solution boiling on the heating mantle. The results were expressed as per cent reducing sugar.

Reducing sugars $(\%)=$

Titre value $\times$ Weight of sample $\times 100$

Factor value $\times$ Dilution

\section{Total sugars (\%)}

Total sugars were determined by the method described by Lane and Eyon (AOAC, 1965). A quantity $(50 \mathrm{ml})$ of lead free filtrate was taken in a $100 \mathrm{ml}$ volumetric flask and to it 5 $\mathrm{ml}$ of concentrated $\mathrm{HCl}$ was added, mixed well and then kept for 24 hours at ambient temperature. Acid was then neutralized with $40 \% \mathrm{NaOH}$ using a drop of phenolphthalein as an indicator till the pink colour persisted a few seconds. The volume was then made up to 100 $\mathrm{ml}$ with distilled water. Total sugars were estimated by titrating against standard 
Fehling's solution mixture of A and B (1:1) using methylene blue as an indicator till it turns to brick red colour as an end point. The results were expressed as per cent total sugar.

Total sugars $(\%)=$

Titre value $\times$ Weight of sample $\times$ Aliquot

Factor value $\times$ Dilution $1 \times$ Dilution 2

\section{Non-reducing sugars (\%)}

Non-reducing sugars were estimated by subtracting reducing sugars from total sugars and expressed as per cent. Non-reducing sugars $(\%)=$ Total sugars $(\%)$ - Reducing sugars $(\%)$

\section{Ascorbic acid (mg $\left.100^{-1} \mathrm{~g}\right)$}

Ten grams of beetroot cube was ground well with 3 per cent metaphosphoric acid and the volume was made up to $100 \mathrm{ml}$ with 3 per cent metaphosphoric acid. The contents were shaken well and filtered through filter paper. $10 \mathrm{ml}$ of the aliquot was taken and titrated against standard dye solution (2,6dichlorophenol indophenol dye) till the light pink colour persisted for at least 15 seconds (Ranganna, 1986). The ascorbic acid content was estimated using the given formula and expressed as $\mathrm{mg} / 100 \mathrm{~g}$ of plant material.

Ascorbic acid $\left(\mathrm{mg}^{\left.100 \mathrm{~g}^{-1}\right)}=\right.$

Titre value $\times$ dye factor $\times$ volume made up

Aliquot taken $\times$ weight of the sample

\section{Betanine (mg $\left.100^{-1} \mathrm{~g}\right)$}

Betanine content of roots was determined at harvest with the procedure suggested by Nilsson (1970) and was expressed in mg 100 $\mathrm{g}^{-1}$ sample.

\section{Shelf life (days)}

The harvested roots were kept for shelf life studies in a laboratory at ambient temperatures. Shelf life of roots was assessed in days based on visual parameters. The number of days was computed from the day of harvest till the root remains in fresh condition and acceptable to the consumer.

\section{Results and Discussion}

The effect of different organic manures viz, FYM, vermicompost, poultry manure, neem cake and green manure at various stages of crop growth in Beetroot with respect to quality is studied. The results of the present investigation on the above aspect are presented hereunder.

\section{Quality parameters}

Data on various quality parameters of beetroot crop as influenced by the different organic manures and their combinations are presented in Tables 1 and 2.

\section{Betanine content $\left(\mathrm{mg} 100 \mathrm{~g}^{-1}\right)$}

The Betanine content of beetroot roots was significantly affected by the different treatments applied to the experiment. The results are presented in Table 1.

The highest betanine (1.93) was recorded in $\mathrm{T}_{7}$ with the application of FYM $(50 \%)+$ Neem cake $(50 \%)$ which was on par with $\mathrm{T}_{3}(1.89)$ with Neem cake (100\%), T 6 with FYM (50\%) + vermicompost $(50 \%)$ and $\mathrm{T}_{8}$ with FYM $(50 \%)+$ poultry manure $(50 \%)$ which were significantly superior to all other treatments. The lowest betanine content (4.30) was recorded in control RDF @ $70 \mathrm{~kg} \mathrm{~N} ; 110 \mathrm{~kg}$ $\mathrm{P}_{2} \mathrm{O}_{5} ; 70 \mathrm{~kg} \mathrm{~K} 2 \mathrm{O}$ recorded betanine content of 1.61 . 


\section{Total soluble solids $\left({ }^{\circ}\right.$ Brix $)$}

The TSS of beetroot roots was significantly affected by the application of Neem cake $(100 \%)$. The results are presented in Table 1.The highest TSS (8.64) was recorded in $\mathrm{T}_{3}$ with the application of neem cake (100\%) followed by $\mathrm{T}_{7}$ (8.29) with FYM $(50 \%)+$ Neem cake $(50 \%)$ which were significantly superior to all other treatments. The lowest TSS content (6.23) was recorded in Control $\left(\mathrm{T}_{11}\right)$.

\section{Ascorbic acid (mg $100^{-1} \mathrm{~g}$ fresh weight)}

The Ascorbic acid of beet root roots was significantly affected by the application of vermicompost $(100 \%)$ and FYM (50\%) + Poultry Manure (50\%). The results are presented in Table 1. The highest ascorbic acid (3.31) was recorded in $\mathrm{T}_{2}$ with the application of Vermicompost (100\%) which was at par (3.28) of $\mathrm{T}_{8}$ with FYM (50\%) + Poultry Manure $(50 \%)$ and were significantly superior to all other treatments. The lowest ascorbic acid content (2.50) was recorded in Control $\left(\mathrm{T}_{11}\right)$.

\section{Reducing sugars (\%)}

The reducing sugars content of beet root roots was significantly affected by the application of FYM $(50 \%)+$ Neem cake $(50 \%)$. The results are presented in Table 2 . The highest reducing sugars content (5.15) was recorded in $\mathrm{T}_{7}$ with the application of FYM $(50 \%)+$ Neem cake (50\%) which was at par with $\mathrm{T}_{6}(5.10)$ with FYM $(50 \%)+$ Vermiompost $(50 \%)$ and were significantly superior to all other treatments. The lowest reducing sugar content (4.58) was recorded in Control $\left(\mathrm{T}_{11}\right)$.

\section{Non-reducing sugars (\%)}

The non-reducing sugars content of beetroot roots was significantly affected by the application of FYM, vermicompost, neem cake, poultry manure and green manure. The results are presented in Table 2 . The highest non-reducing sugars content (2.26) was recorded in $\mathrm{T}_{7}$ with the application of FYM $(50 \%)+$ Neem cake $(50 \%)$ which was at par with $\mathrm{T}_{6}$ (2.23) with FYM (50\%) + Vermicompost (50\%) and were significantly superior to all other treatments. The lowest non-reducing sugar content (1.78) was recorded in FYM $(50 \%)+$ green manure $(50 \%)$ and was on par with $\mathrm{T}_{10}(1.81), \mathrm{T}_{9}$ (1.78), $\mathrm{T}_{5}$ (1.86) and $\mathrm{T}_{2}$ (1.88).

\section{Total sugars $(\%)$}

The total sugars content of beetroot roots was significantly affected by the application of FYM, vermicompost, neem cake, poultry manure and green manure. The results are presented in Table 2.The highest total sugar content (7.40) was recorded in $\mathrm{T}_{7}$ with the application of FYM $(50 \%)+$ Neem cake $(50 \%)$ which was at par with $\mathrm{T}_{6}(7.33)$ with FYM $(50 \%)+$ Vermicompost $(50 \%)$ and were significantly superior to all other treatments. The lowest total sugars content (6.43) was recorded in control, which was on par with $\mathrm{T}_{10}$ (6.45), $\mathrm{T}_{9}$ (6.48), $\mathrm{T}_{5}$ (6.50) and $\mathrm{T}_{2}$ (6.54).

Improvement in quality of beetroot with the application of organic manures over inorganic fertilizers was observed. The betanin $(1.93 \mathrm{mg}$ $\left.100 \mathrm{~g}^{-1}\right)$, TSS (8.64 ${ }^{\circ}$ Brix), ascorbic acid (3.31) were higher with the application of FYM $(50 \%)$ + poultry manure $(50 \%)$ and sole application of neemcake (100\%), vermicompost (100\%) respectively, Reducing sugars $(5.15 \%)$, nonreducing sugars $(2.26 \%)$ and total sugars content (7.40\%) were higher with the application of neem cake in combination with FYM. This may be because of better availability and uptake of nitrogen and other nutrients with the application of manures which might have lead to balanced $\mathrm{C} / \mathrm{N}$ ratio and increased activity of plant metabolism. Similar findings were made by Singh et al., (1970), Matura (1961) and Emura and Hosoya (1979) in carrot. 
Table.1 Effect of different organic manures on betanine content (mg $\left.100 \mathrm{~g}^{-1}\right)$, TSS (\%) and ascorbic acid (mg $\left.100 \mathrm{~g}^{-1}\right)$ of Beet root at harvest

\begin{tabular}{|c|c|c|c|}
\hline Treatments & Betanine & TSS & Ascorbic acid \\
\hline FYM $(100 \%)$ & 1.76 & 7.84 & 2.87 \\
\hline Vermicompost (100\%) & 1.75 & 8.05 & 3.31 \\
\hline Neem cake $(100 \%)$ & 1.89 & 8.64 & 2.90 \\
\hline Poultry Manure (100\%) & 1.72 & 8.17 & 2.87 \\
\hline Green Manure (100\%) & 1.71 & 7.38 & 2.90 \\
\hline FYM (50\%) + Vermicompost (50\%) & 1.83 & 8.09 & 2.80 \\
\hline FYM $(50 \%)+$ Neem cake $(50 \%)$ & 1.93 & 8.29 & 2.76 \\
\hline FYM (50\%) + Poultry Manure (50\%) & 1.81 & 7.74 & 3.28 \\
\hline FYM (50\%) + Green Manure (50\%) & 1.65 & 7.54 & 2.81 \\
\hline RDF @ $70 \mathrm{~kg} \mathrm{N;} 110 \mathrm{~kg} \mathrm{P}_{2} \mathrm{O}_{5} ; 70 \mathrm{~kg} \mathrm{~K} \mathrm{O}$ & 1.61 & 7.01 & 2.56 \\
\hline Control & 1.54 & 6.23 & 2.50 \\
\hline $\mathrm{CD}$ at $5 \%$ & 0.14 & 0.24 & 0.17 \\
\hline $\mathrm{SE}(\mathrm{m}) \pm$ & 0.05 & 0.08 & 0.06 \\
\hline
\end{tabular}

Table.2 Effect of different organic manures on Sugars (\%) and storage life (days) of Beet root at harvest

\begin{tabular}{|c|c|c|c|c|}
\hline Treatments & $\begin{array}{c}\text { Reducing } \\
\text { Sugars }\end{array}$ & $\begin{array}{l}\text { Non- } \\
\text { reducing }\end{array}$ & $\begin{array}{c}\text { Total } \\
\text { Sugars }\end{array}$ & Shelf life \\
\hline FYM (100\%) & 4.70 & 2.01 & 6.70 & 3.10 \\
\hline Vermicompost (100\%) & 4.66 & 1.88 & 6.54 & 4.43 \\
\hline Neem cake $(100 \%)$ & 4.93 & 2.10 & 7.02 & 2.76 \\
\hline Poultry Manure (100\%) & 4.87 & 2.00 & 6.87 & 3.20 \\
\hline Green Manure (100\%) & 4.65 & 1.86 & 6.50 & 3.43 \\
\hline FYM (50\%) + Vermicompost (50\%) & 5.10 & 2.23 & 7.33 & 4.10 \\
\hline FYM $(50 \%)+$ Neem cake $(50 \%)$ & 5.15 & 2.26 & 7.40 & 3.76 \\
\hline FYM $(50 \%)+$ Poultry Manure (50\%) & 4.88 & 2.09 & 6.97 & 3.10 \\
\hline FYM (50\%) + Green Manure (50\%) & 4.71 & 1.78 & 6.48 & 3.43 \\
\hline RDF @ $70 \mathrm{~kg} \mathrm{~N} ; 110 \mathrm{~kg} \mathrm{P}_{2} \mathrm{O}_{5} ; 70 \mathrm{~kg} \mathrm{~K}_{2} \mathrm{O}$ & 4.64 & 1.81 & 6.45 & 3.10 \\
\hline Control & 4.58 & 1.85 & 6.43 & 2.60 \\
\hline $\mathrm{CD}$ at $5 \%$ & 0.14 & 0.16 & 0.25 & 0.51 \\
\hline $\mathrm{SE}(\mathrm{m}) \pm$ & 0.05 & 0.06 & 0.09 & 0.17 \\
\hline
\end{tabular}


Indumati (2000) reported an increase in TSS content with the application of vermicompost besides other organic manures and with recommended dose of fertilizers in radish. Kolodzieg and Kostecka (1994) also observed better root quality when carrot was grown with vermicompost than mineral fertilizers. Increase in carotene content with the increasing dosage of vermicompost was also reported by Ravindrababu (1999). Hallmann (2012) showed an increase in the total content of sugars and in a higher sugar to organic acids ratio in organic tomatoes when compared to these produced conventionally. Rembiałkowska et al., (2012) confirmed a higher content of total sugars in organic fruits and vegetables, including carrots, beets, potatoes, spinach, kale, cherries, black currants and apples, which contribute to an increase in the technological and sensory quality (taste) of organic products.

Kale et al., (1992) observed that vermicompost application enhanced the activity of beneficial microbes and colonization of mycorrhizal fungi which play an important role in mobilization of nutrients by plants. Thus, leading to better availability of nutrients and uptake by plants and resulting in better quality.

\section{Storage life (days)}

The storage life of Beetroot was significantly affected by the application of FYM, vermicompost, neem cake, poultry manure and green manure. The results are presented in Table 2. The highest storage life (4.43) was recorded in $\mathrm{T}_{2}$ with the application of vermicompost $(100 \%)$ followed by $\mathrm{T}_{6}(4.10)$ with vermicompost (50\%) + FYM (50\%) which were significantly superior to all other treatments. The lowest storage life (2.60) was recorded in control. The higher storage life of Beetroot with the application of vermicompost may be because of low respiration rate.
In conclusion, all the quality parameters were improved significantly with the organic manures over inorganic fertilizers. The highest betanine (1.93) content was recorded with FYM $(50 \%)$ + neem cake $(50 \%)$ which was at par (1.89) with neem cake (100\%), FYM $(50 \%)$ + vermicompost (50\%) (1.83) and FYM $(50 \%)+$ poultry manure $(50 \%)$ (1.81). The highest total soluble solids (8.64) was recorded with neem cake $(100 \%)$ which was at par with FYM $(50 \%)$ + neem cake (50\%) (8.29). The highest ascorbic acid (3.31) was recorded with vermicompost (100\%) which was at par with FYM $(50 \%)+$ poultry manure $(50 \%)$ (3.28). The highest reducing sugars (5.15) was recorded with FYM (50\%) + neem cake $(50 \%)$ which was at par $(5.10)$ with FYM (50\%) + Vermicompost (50\%). The highest non reducing sugars (2.26) was recorded with FYM (50\%) + neem cake $(50 \%)$ which was at par (2.23) with FYM $(50 \%)+$ Vermicompost $(50 \%)$. The highest total sugar content (7.40) was recorded with FYM $(50 \%)+$ neem cake $(50 \%)$ which was at par (7.33) with FYM (50\%) + Vermicompost $(50 \%)$. Storage life was maximum (4.43 days) with the application of vermicompost (100\%) which was at par with FYM (50\%) + vermicompost (50\%) (4.10 days).

\section{References}

Ado, P.O., 1999. Beetroot Cultivation. Beetroot and Eggplant Newsletter, 18: $21-24$.

Association of Official Agricultural Chemista (AOAC). 1969. Official and tentative methods of analysis. Association of Official Agricultural Chemists. Washington D C.

Deuter, P. and Grundy, T. (2004). Beetroot Commercial Production and Processing. Agency for Food and Fibre Sciences. Holland Horticultural Limited Partnership. P. 1 - 4.

Emura, K and Hosoya, T. 1979. Effect of 
fertilization on the quality and yield of spring sown carrots. Bulletin of the Saitawa Horticultural Experimental Station. Pp:13-23. HA: 50(12)- 9153. Hallmann E, Rembiałkowska E (2012). Characterisation of antioxidant compounds in sweet bell pepper (Capsicum annuum L.) under organic and conventional growing systems. J Sci Food Agri, DOI 10.1002/jsfa.5624.

Indumathi, S. 2000. Integrated nutrient management in radish (Raphanus sativus L.) M.Sc. thesis submitted to Acharya N. G. Ranga Agricultural University, Hyderabad.

Kale, R.M, Mallesh, B.C, Bano, K and Bagyaraj, D.J. 1992. Influence of vermicompost application on the available macro nutrients and selected microbial population in paddy field. Soil Biology and Biochemistry. 24 (12): 1317-1320.

Kolodzieg, M and Kostecka, J. 1994. Some quality characteristics in cucumber and carrots grown on vermicompost. Zeszyty - Navkowe - Akademii - Rolniczej. In
Hugona - Kallataja - Krakowie - Sesja - Naukowa. 41 : 89-93.

Matura, H. 1961. A study on year round cultured vegetables containing pigments other than chlorophyll.

Nilsson. T. 1970. Studies in to the pigments in beetroot (Beta vulgaris L. ssp. Vulgaris var. rubra L.) Lantbrukshogsk Ann. 36: 179-197.

Ranganna. S. 1994. Hand book of analysis and quality control for fruits and vegetable products. Tata McGraw Hill Publishing Company limited. New Delhi.

Ravindrababu, M. 1999. Studies on integrated nutrient management with vermicompost and inorganic fertilizers in carrot (Dacus carota L.). M.Sc. Thesis submitted to Acharya N. G. Ranga Agricultural University

Singh, K, Gill, J.S and Verma, O.P. 1970. Studies on poultry manure in relation to vegetable production. Indian Journal of Horticulture. 27- 42-47.

\section{How to cite this article:}

Chitti Jagadeesh, M. Madhavi, V.V. Padmaja and Siva Prasad, M. 2018. Effect of Organic Manures on Quality and Shelf Life of Beet Root Cv. Crimson Globe. Int.J.Curr.Microbiol.App.Sci. 7(11): 3615-3621. doi: https://doi.org/10.20546/ijcmas.2018.711.414 